\title{
Prevalence of Toxoplasma gondii Antibodies and DNA in Iranian HIV Patients
}

\author{
Anahita Bavand ${ }^{1}$, Arezoo Aghakhani2 ${ }^{*}$, Minoo Mohraz ${ }^{3}$, Mohammad Banifazl $^{4}$, Afsaneh Karami $^{5}$, \\ Majid Golkar ${ }^{6}$, Jalal Babaie ${ }^{6}$, Parviz Saleh ${ }^{7}$, Setareh Mamishi ${ }^{8}$, Amitis Ramezani ${ }^{* *}$ \\ 1. MSc, Dept. of Clinical Research, Pasteur Institute of Iran, Tehran, Iran \\ 2. Anatomical \& Clinical Pathologist, Dept. of Clinical Research, Pasteur Institute of Iran, Tehran, Iran \\ 3. Infectious Diseases Specialist, Iranian Research Center for HIVIAIDS, Tehran, Iran \\ 4. Pediatrician, Iranian Society for Support of Patients with Infectious Disease, Tehran, Iran \\ 5. Infectious Diseases Specialist, Zanjan University of Medical Sciences, Zanjan, Iran \\ 6. PhD, Molecular Parasitology Laboratory, Dept. of Parasitology, Pasteur Institute of Iran, Tehran, Iran \\ 7. Infectious Diseases Specialist, Kidney Research Center, Tabriz University of Medical Sciences, Tabriz, Iran \\ 8. Pediatrician, Pediatric Infectious Disease Research Center, Tehran University of Medical Sciences, Tehran, Iran \\ 9. Infectious Diseases Specialist, Dept. of Clinical Research, Pasteur Institute of Iran, Tehran, Iran
}

\begin{tabular}{c}
\hline KEYWORDS \\
\hline Human Immunodeficiency \\
Virus (HIV), \\
IgG, \\
IgM, \\
Toxoplasma gondii, \\
Reactive Inhibition \\
Antibodies \\
\hline
\end{tabular}

Article Info

Received 01 Sept 2018;

Accepted 24 Dec 2018; Published Online 27 Dec 2018;

Doi: 10.30699/IJP.14.1.68

\section{ABSTRACT}

Background \& Objective: Toxoplasma gondii infection has public health importance and can lead to serious diseases in immunosuppressed patients, such as HIV cases. Appropriate control of $T$. gondii infection in HIV patients requires information about the prevalence of $T$. gondii antibodies and DNA in different population. In this study, we aimed to determine the prevalence of Toxoplasma gondii antibodies and DNA in HIV patients in Tehran, Iran.

Methods: A total of 149 HIV patients from the Iranian Research Center for HIV/ AIDS, Tehran, Iran were enrolled in the study. Anti-Toxoplasma IgG and IgM were detected by ELISA and T. gondii DNA was evaluated by PCR and quantitative realtime PCR. IgG positive samples were also assessed for their avidity.

Results: Anti-Toxoplasma IgG and IgM were positive in $46.3 \%$ and $2.7 \%$ of cases respectively. $92.7 \%$ of our patients showed past infection and $4.3 \%$ revealed recently acquired toxoplasmosis based on their IgG avidity test. T. gondii DNA was not detected by PCR but real-time PCR results showed DNA in $4.7 \%$ of total patients and $13.1 \%$ of the $\mathrm{IgG}$ seropositive cases.

Conclusion: Our findings indicated that latent toxoplasmosis was relatively prevalent in our study population, but new T. gondii infection had low prevalence. Almost half of our patients were IgG negative and at risk of acquiring toxoplasma infection. Low copy numbers of DNA were detected in $4.7 \%$ of the cases without any clinical manifestation. Therefore, detection and monitoring of anti-Toxoplasma antibodies and DNA in HIV patients is substantial to estimate the risk of reactivation and new infection.

\footnotetext{
Corresponding Information:

Tehran, Iran. Email: amitisramezani@hotmail.com

Arezoo Aghakhani, Anatomical\& Clinical Pathologist, Clinical Research Dept., Pasteur Institute of Iran,

Tehran, Iran. Email: araghakhani@hotmail.com
}

Amitis Ramezani, Infectious Diseases Specialist, Clinical Research Dept., Pasteur Institute of Iran,

Copyright (c) 2019. This is an open-access article distributed under the terms of the Creative Commons Attribution-noncommercial 4.0 International License which permits copy and redistribute the material just in noncommercial usages, provided the original work is properly cited.

\section{Introduction}

Toxoplasmosis is a parasitic disease caused by Toxoplasma gondii (T. gondii), an obligate intracellular parasite. It has a wide distribution and it affects almost $30 \%$ of the world's population, with a variable prevalence in different countries (1).

In the majority of immunocompetent individuals, T. gondii infection is a subclinical and asymptomatic disease which may lead to latent infection characterized by the persistence of the organism within host 
tissues without any symptoms (2). However T. gondii can lead to acute and life-threatening disease in immunocompromised people such as HIV individuals, cases with malignancy and subjects receiving organ transplantation $(3,4)$. T. gondii infection is considered as one of the most important opportunistic infections in patients with HIV, and is also considered as the main cause of morbidity and mortality in these patients $(5,6)$.

The prevalence of $T$. gondii infection in HIV patients varies throughout the world. The overall seroprevalence rate reported is $35.8 \%$ but based on the region it differs from $60.7 \%$ in the Middle East and North Africa to reach $49.1 \%$ in Latin America, $44.9 \%$ in subSaharan Africa, 30.1\% in western and central Europe and North America while it is $25.1 \%$ in Asia and the Pacific (7).

The main cause of toxoplasmosis in an HIV patient is the reactivation of latent infection particularly in the brain, leading to toxoplasmic encephalitis (TE), especially when CD4 count reduces to less than 100 cells $/ \mathrm{mm}^{3}$ (7). Patients with toxoplasmosis and HIV co-infection have 30 to $40 \%$ risk of TE (8). This is a fatal infection in HIV patients without receiving antiretroviral therapy (9).

Serological tests are used for the diagnosis of toxoplasmosis, but these tests are not reliable in immunocompromised patients due to suppression of the immune system. Molecular tests are now considered as important method for the diagnosis of toxoplasma infection in immunosuppressed individuals, especially when serological techniques fail (10). Some authors mentioned the association of $T$. gondii $\mathrm{IgG}$ antibodies and DNA with the reactivation of toxoplasmosis and its clinical manifestation in HIV patients $(11,12)$.

However, appropriate diagnosis and control of $T$. gondii infection in HIV patients require adequate information regarding the prevalence of $T$. gondii antibodies and DNA in different population. Due to limited data on molecular diagnosis of Toxoplasma infection and its association to $T$. gondii antibodies in Iranian HIV patients, we aimed to determine the prevalence of Toxoplasma gondii antibodies and DNA in
HIV patients in Tehran, Iran.

\section{Materials and Methods}

\section{Study Population}

In this cross-sectional study, 149 HIV patients who were referred to the Iranian Research Center for HIV/ AIDS in Tehran, Iran were consecutively enrolled from May to September 2017. The study protocol was approved by the Pasteur Institute of Iran Ethical Committee and informed consent was obtained from subjects prior to the study.

CD4 count was determined by flowcytometry and defined as cells $/ \mathrm{mm} 3$.

\section{Detection of Anti-Toxoplasma IgG and IgM An- tibodies}

All plasma samples were screened using the standard enzyme-linked immunosorbent assay (ELISA) commercial kits for the detection of anti-Toxoplasma IgG and IgM antibodies (EUROIMMUN, Lubek, Germany) in accordance with the manufacturer's instructions.

\section{Assessment of IgG Avidity}

For differentiation between recently acquired and past infection of $\mathrm{T}$. gondii infection, anti-Toxoplasma IgG positive specimens were subjected for IgG avidity test using ELISA kit (EUROIMMUN, Lubek, Germany). A result of $<40 \%$ was interpreted as low avidity (T. gondii infection was acquired within the last 3 months) between $40-60 \%$ as equivocal range and $>60 \%$ as high avidity (Toxoplasma infection was acquired more than 3 months ago).

\section{DNA Extraction and Polymerase Chain Reaction}

Toxoplasma-DNA was extracted from $200 \mu$ of whole blood using QIAamp® DNA Mini Kit (QIAGEN, Hilden, Germany) according to manufacturer's instructions.

In order to evaluate the suitability of the extracted DNA, $\beta$-globin gene amplification was performed using PCO3 (5'-ACACAACTGTGTTCACTAGC-3') and PCO4 (5'- CAACTTCATCCACGTTCACC-3') primers which amplify a 110-bp fragment. PCR was carried out in a $25 \mu \mathrm{l}$ amplification mixture containing 
$1 \mu 1$ of extracted DNA, $1.5 \mathrm{mM} \mathrm{MgCl} 2,15 \mathrm{mM}$ Tris$\mathrm{HCl}$ ( $\mathrm{pH} 8.0$ ), $0.2 \mathrm{mM}$ dNTP, $50 \mathrm{mM} \mathrm{KCl}, 10$ pmol of each of primers and $1.5 \mathrm{U}$ Taq polymerase (YTA PCR Master Mix, Iran). $\beta$-globin positive samples were subjected to PCR.

Polymerase chain reaction was carried out using primer pair TOXO1 (CGCTGCAGGGAGGAAGACGAAAGTTG) and TOXO2 (CGCTGCAGACACAGTGCATCTGGATT) which were selected from the 50 and 30 end of the 529 bp fragment (RE) respectively. The PCR reaction was performed in a $25 \mathrm{ml}$ reaction mixture containing $15 \mathrm{mM}$ Tris- $\mathrm{HCl}(\mathrm{pH} 8)$, $50 \mathrm{mM} \mathrm{KCl}, 1.5 \mathrm{mM} \mathrm{MgCl}, 0.2 \mathrm{mM}$ dNTP, $10 \mathrm{pmol}$ of each primer and 1.5 U Taq polymerase (YTA PCR Master Mix, Iran). Amplification was performed as initial 7 minute ( $\mathrm{min}$ ) denaturation at $94^{\circ} \mathrm{C}$, followed by 35 cycles of amplification including denaturation for $1 \mathrm{~min}$ at $94^{\circ} \mathrm{C}$, annealing for $1 \mathrm{~min}$ at $55^{\circ} \mathrm{C}$ and extension for $1 \mathrm{~min}$ at $72^{\circ} \mathrm{C}$. Strand synthesis was completed at $72^{\circ} \mathrm{C}$ for $10 \mathrm{~min}$ and stored in $4^{\circ} \mathrm{C}$ for 5 min. The expected size of the PCR product was 529 bp. Each batch included negative control containing water and extracted DNA from $T$. gondii tachyzoites $\mathrm{RH}$-strain as positive control.

The PCR products were electrophoresed on a $1.5 \%$ agarose gel with the 100-bp DNA ladder (Sinaclon, Iran) and stained with DNA stain and visualized by ultraviolet transillumination.

\section{Quantitative Real Time PCR Assays}

Quantitative Real time PCR Assays for REP-529 was performed according to the method previously described by Babaie et al. (13). Real time PCR was conducted using a BIO-RAD DNA Engine Thermal Cycler under the following conditions: an initial denaturation at $95^{\circ} \mathrm{C}$ for $10 \mathrm{~min}$, followed by 35 cycles of $30 \mathrm{sec}$ at $95^{\circ} \mathrm{C}, 30 \mathrm{sec}$ at $58^{\circ} \mathrm{C}$ and $30 \mathrm{sec}$ at $72^{\circ} \mathrm{C}$. The final extension step was set for $20 \mathrm{~min}$ at $72^{\circ} \mathrm{C}$. The analytical detection limit of assay is 10 copies per PCR reaction $(25 \mu 1)$.

\section{Statistical Analysis}

Statistical analyses were conducted using SPSS statistics software (version 16, Chicago, IL, USA). The Chi square test or Fisher's exact test was used to compare variables. Data is presented as mean $\pm \mathrm{SD}$ or, when indicated, as an absolute number and percentage. $P$-values $<0.05$ were considered statistically significant.

\section{Results}

A total of 149 HIV infected patients between the ages of 18 to 74 years (mean age of $39.52 \pm 8.07$ ) including $81.2 \%$ male and $18.8 \%$ female were enrolled in the study. The most possible routes of HIV transmission were intravenous drug use (17.2\%), heterosexual contact (27.6\%), infected blood and blood products $(2.8 \%)$, vertical transmission $(0.7 \%)$, homosexual (2.8\%), tattoo (1.4\%), IDU and heterosexual (7.6\%), IDU and tattoo (6.9\%), heterosexual and tattoo $(0.7 \%)$, homosexual and heterosexual $(0.7 \%)$, IDU and heterosexual and tattoo (20\%), IDU and heterosexual and blood transfusion $(0.7 \%)$, IDU and heterosexual and homosexual (1.4\%) and in $9.7 \%$ the route of HIV acquisition was not identified. The mean CD4 count was $458.08 \pm 268.267$ cells $/ \mathrm{mm} 3.78 .5 \%$ of patients receiving highly active antiretroviral therapy (HAART).

$2.7 \%(4 / 149)$ of the cases were positive for antiToxoplasma IgM and 46.3\% (69/149) were positive for IgG antibodies, of which 64 (92.7\%) cases showed past infection and $3(4.3 \%)$ patients revealed recently acquired toxoplasma infection according to their $\mathrm{IgG}$ avidity test. 2 (2.9\%) subjects demonstrated equivocal IgG avidity range. $53.7 \%$ of our HIV cases were IgG negative and at risk of acquiring Toxoplasma infection.

Three out of four IgM positive cases had IgG simultaneously and all 3 cases had low IgG avidity with CD4 count $\geq 500$ cells $/ \mathrm{mm}^{3}$, only one subject was IgM positive.

All cases were categorized in four age groups as: $18-28,29-39,40-49$, and $\geq 50$ years. The highest (49.3\%) and the lowest (33.3\%) IgG antibody rates were found within the age groups of 40-49 and 18-28 years old, respectively (table 1). The IgG seroprevalence was slightly higher in females $(50 \%)$ than in males (45.5\%) (Not significant). 
71.Prevalence of Toxoplasma gondii Antibodies...

Table 1. Frequency of Toxoplasma DNA and antibodies based on age in HIV positive patients

\begin{tabular}{|c|c|c|c|c|}
\hline Age groups & $\mathbf{N}(\%)$ & $\begin{array}{c}\text { Anti -Toxoplasma } \\
\text { IgM }\end{array}$ & Anti-Toxoplasma IgG & T. gondii DNA \\
\hline $18-28$ & $9(6 \%)$ & $0(0 \%)$ & $3(33.3 \%)$ & $0(0 \%)$ \\
\hline $29-39$ & $74(49.7 \%)$ & $1(0.7 \%)$ & $26(35.1 \%)$ & $12(8.1 \%)$ \\
\hline $40-49$ & $53(35.6 \%)$ & $3(2 \%)$ & $34(49.3 \%)$ & $7(4.7 \%)$ \\
\hline $50 \leq$ & $13(8.7 \%)$ & $0(0 \%)$ & $6(46.2 \%)$ & $0(0 \%)$ \\
\hline
\end{tabular}

Human immunodeficiency virus (HIV)

T. gondii DNA was not detected by PCR, but quantitative real-time PCR results showed $T$. gondii DNA in $7(4.7 \%)$ patients. The titers of $T$. gondii DNA was from 10 to 28.39 copies per reaction $(25 \mu 1)$. From seven DNA positive samples, 4 cases had IgG simultaneously with high IgG avidity. One case had IgM, $\mathrm{IgG}$ and DNA concurrently with low IgG avidity (probably ongoing infection) and only 2 subjects were DNA positive. Out of seven DNA positive cases, six subjects were injecting drug users with a past history of incarceration.

From 69 IgG positive cases, T. gondii DNA was detected in $5(13.1 \%)$ patients. Furthermore, 2.5\% $(2 / 80)$ of serology negative patients showed positive PCR results.

The rate of Toxoplasma gondii antibodies and DNA based on CD4 counts were shown in Table 2. There was no significant difference between anti-Toxoplasma antibodies rate and DNA frequency with mean CD4 count.

Table 2. Rate of Toxoplasma gondii antibodies and DNA based of CD4 counts in our cohort of study

\begin{tabular}{|c|c|c|c|c|}
\hline \multirow{2}{*}{ CD4 count (cells $\left./ \mathbf{m m}^{3}\right)$} & 0-99 & 100-199 & $200-499$ & $500 \leq$ \\
\hline & N (\%) & $\mathbf{N}(\%)$ & $\mathbf{N}(\%)$ & $\mathbf{N}(\%)$ \\
\hline Total of patients & $6(4.1 \%)$ & $11(7.6 \%)$ & $75(51.7 \%)$ & $53(36.6 \%)$ \\
\hline Anti-Toxoplasma IgM positive patients & $0(0 \%)$ & $0(0 \%)$ & $0(0 \%)$ & $4(100 \%)$ \\
\hline Anti-Toxoplasma IgG positive patients & $3(50 \%)$ & $4(36.4 \%)$ & $38(50.7 \%)$ & $23(43.4 \%)$ \\
\hline DNA positive patients & $0(0 \%)$ & $1(9.1 \%)$ & $5(6.7 \%)$ & $1(1.9 \%)$ \\
\hline
\end{tabular}

Human immunodeficiency virus (HIV)

\section{Discussion}

This study investigated the prevalence of Toxoplasma gondii antibodies and DNA in HIV patients in Tehran, Iran. Anti-Toxoplasma IgG and IgM were positive in $46.3 \%$ and $2.7 \%$ of the cases respectively and $4.7 \%$ of the subjects were positive for $T$. gondii
DNA by real time PCR. $92.7 \%$ of our patients showed past infection and $4.3 \%$ revealed recently acquired toxoplasmosis based on their IgG avidity test.

Co-infection of $T$. gondii and HIV infection is a major public health issue which can affect the course of both infections by the interaction of two pathogens 
and by suppressing host immune system (14). Almost half of the HIV individuals have co-infection with $T$. gondii $(15,16)$.

Seroprevalence of Toxoplasma infection varies greatly worldwide due to socioeconomic conditions, cultural habits, different lifestyles, climate, geographical areas, age, residing in rural areas, educational status and having raw or undercooked meat (17). Different studies reported the seroprevalence rate of $T$. gondii in HIV patients from less than $10 \%$ to over $90 \%$ in different countries and even within one country, this variation is substantial (7). This seroprevalence is also very variant in the different parts of Iran (15, 18-21). Even in Tehran, two different seroprevalence rates were reported by Rostami (22) and Mohraz et al. (19.1\% and 49.7\% retrospectively) (23). Our finding is consistent with Mohraz et al. study but the rates are much higher than what is expressed in Rostami et al. survey regarding $T$. gondii seroprevalence rate in Tehran.

Serologic tests such as IgM and $\operatorname{IgG}$ are the main methods for diagnosis of toxoplasmosis but these assays constitute some difficulties to differentiate acute form from chronic and the reactivation of infection (24). The detection of anti-T.gondii IgM as a routine diagnostic test of toxoplasmosis has some limited value in the management of HIV patients (25). The IgG avidity test is a qualitative assay which distinguishes chronic toxoplasmosis from a recently acquired infection and determines the status of toxoplasma infection. Low IgG avidity suggests acute infection, while high IgG avidity indicates chronic or reactivated infection $(26,27)$.

Walle et al. found anti-T.gondii $\operatorname{IgM}$ in $10.7 \%$ of HIV individuals (28). A study from India detected $6 \%$ anti-T.gondii IgM in HIV cases (29). Zeleke et al found toxoplasma IgM antibody in $2.2 \%$ of HIV positive women in reproductive age and all IgM positive samples were positive for IgG concurrently (30). They found low rate of $T$. gondii $\operatorname{IgM}(2.2 \%)$ in comparison to IgG (94.4\%). Same results in HIV patients reported from Mexico and South Africa $(31,32)$. We also found low rate of $T$. gondii $\operatorname{IgM}$ in comparison to
IgG and three from four our IgM positive cases had IgG simultaneously with low IgG avidity. Additionally, an overall $4.3 \%$ of our cases had low IgG avidity which indicates recently acquired Toxoplasma infection and such is not common in our cases. This data emphasizes that the reactivation of chronic $T$. gondii infection is the dominant way of acquiring toxoplasmosis in HIV cases that is not a new infection $(32,33$, 34). However, incidence of reactivation is associated with the prevalence and concentration of $T$. gondii IgG antibodies (35).

Today, molecular methods are known as important diagnostic tools for the detection of toxoplasmosis in immunosuppressed hosts (10). Some authors mentioned that the detection of $T$. gondii DNA in the blood indicates active infection and is closely associated with clinical manifestation of HIV patients $(11,12)$ while other molecular studies on HIV patients without cerebral toxoplasmosis did not confirm this association. Gashout et al. detected T.gondii DNA in $60 \%$ of asymptomatic seropositive HIV patients with a CD4 count less than 100 cells/ $\mu 1$ (10). In another study, Toxoplasma DNA was detected in $25 \%$ of HIV patients in stages 3 and 4 with positive $T$. gondii IgG (36). Ayi et al. detected T. gondii DNA in $54.7 \%$ of HIV seropositive subjects and DNA was found frequently in cases with lower CD4 count (11). In an investigation in Brazil on AIDS patients without cerebral toxoplasmosis, only $2.34 \%$ of patients had T.gondii DNA (12). Rostami et al. from Iran reported only one positive PCR sample in their HIV cohort (22). In our study, T. gondii DNA was observed in $13.1 \%$ of the seropositive cases, which is less than several surveys conducted on the same population but is in agreement with Rostami et al. and Colombo et al. surveys $(12,22)$. However, we enrolled a low number of patients with a CD4 count less than 100 and most of our patients receiving HAART without clinical manifestation of toxoplasmosis. Hence, we should expect a low number of DNA positive cases in this study. Although the presence of Toxoplasma DNA in blood could indicate a recent infection or clinically active disease but reversely, it can be just due to shedding a low amount of parasites from tissue cysts into 
the blood at a subclinical value, especially in asymptomatic cases which is detectable only by real time PCR (37).

Furthermore, in our study, two patients $(2.5 \%)$ with negative serology showed positive real time PCR results, but we should consider that negative serology does not exclude the risk of toxoplasmosis reactivation $(38,39$, and 40).

\section{Conclusion}

We evaluated the total burden of T. gondii infection by measuring $T$. gondii $\operatorname{IgG}, \operatorname{IgM}, \operatorname{IgG}$ avidity test and DNA in Iranian HIV patients. Our data showed that latent toxoplasmosis was relatively prevalent in our study population, but new $T$. gondii infection had low prevalence. However, almost half of our HIV popu- lation was $\operatorname{IgG}$ negative and at risk of acquiring infection. Low copy numbers of $T$. gondii DNA were detected in $4.7 \%$ of the total patients and $13.1 \%$ of seropositive cases were without any clinical manifestation. As appropriate control of $T$. gondii infection in HIV patients is very important, the detection and monitoring of anti-Toxoplasma antibodies and DNA in HIV patients is substantial to estimate the risk of reactivation and new infection.

\section{Acknowledgements}

The authors are grateful to Pasteur Institute of Iran for financial support of this study.

\section{Conflicts of Interest}

The authors declared no conflict of interest.

\section{References}

1. Agrawal SR, Singh V, Ingale S, Jain AP. Toxoplasmosis of spinal cord in acquired immunodeficiency syndrome patient presenting as paraparesis: a rare entity. J Glob Infect Dis. 2014; 6: 178-81. https://doi. org/10.4103/0974-777X.145248 PMID:25538456

2. Antinori A, Larussa D, Cingolani A, Lorenzini P, Bossolasco S, Finazzi MG, et al. Prevalence, associated factors, and prognostic determinants of AIDS-related toxoplasmic encephalitis in the era of advanced highly active antiretroviral therapy. Clin Infect Dis. 2004; 39(11):1681-91. https://doi. org/10.1086/424877 PMID: $\underline{15578371}$

3. Ayi I, Kwofie KD, Blay EA, Osei JH, Frempong KK, Koku R, et al. Clonal types of Toxoplasma gondii among immune compromised and immune competentindividuals in Accra, Ghana. Parasitol Int. 2016; 65(3):238-44. https://doi.org/10.1016/j. parint.2016.01.004 PMID:26775819

4. Babaie J, Sayyah M, Fard-Esfahani P, Golkar M, Gharagozli K. Contribution of dopamine neurotransmission in proconvulsant effect of Toxoplasma gondiiinfection in male mice. J Neurosci Res. 2017; 95(10):1894-1905. https://doi.org/10.1002/jnr.24036 PMID:28266723
5. Botterel F, Lchai P, Feray C, Bouree P, Saliba F, Tur Raspa R, et al. Disseminated toxoplasmosis resulting from infection of a allograft, after orthotropic liver transplantation: useful of quantitative PCR. J Clin Microbiol. 2002; 40(5):1648-1650. https://doi.org/10.1128/JCM.40.5.1648-1650.2002 PMID:11980935 PMCid:PMC130685

6. Cheesbrough M. District laboratory practice in tropical countries. Cambridge: Cambridge University Press; 2006. https://doi.org/10.1017/ $\underline{\mathrm{CBO} 9780511543470}$

7. Chemoh W, Sawangjaroen N, Siripaitoon P, Andiappan H, Hortiwakul T, Sermwittayawong N, et al. Toxoplasma gondii - Prevalence and Risk Factors in HIV-infected Patients from Songklanagarind Hospital, Southern Thailand. Front Microbiol. 2015;6:1304 PMID:26635769 PMCID:PMC4658439

8. Colombo FA, Vidal JE, Penalva de Oliveira AC, Hernandez AV, Bonasser-Filho F, et al.Diagnosis of cerebral toxoplasmosis in AIDS patients in Brazil: importance of molecular and immunological methods using peripheral blood samples. J Clin Microbiol. 2005; 43(10):5044-7. https://doi.org/10.1128/ JCM.43.10.5044-5047.2005 PMID:16207959

9. Daryani A, Sharif M, Meigouni M. Seroprevalence of IgG and IgM anti-Toxoplasma antibodies in HIV/ 
AIDS patients, Northern Iran. Asian Pac. J. Trop. Med. 2011; 4: 271-274. https://doi.org/10.1016/ $\underline{\mathrm{S} 1995-7645(11) 60084-9}$

10. Davarpanah MD, Mehrabani D, Neirami R, Ghahramanpoori M, Darvish M. Toxoplasmosis in HIV/ AIDS patients in Shiraz, southern Iran. Iranian Red Cress Med J. 2007; 9(1):22-27.

11. Garweg J, Boehnke M, Koerner F. Restricted applicability of the polymerase chain reaction for the diagnosis of ocular toxoplasmosis. Ger J Ophthalmol. 1996; 5(2):104-8.

12. Gashout A, Amro A, Erhuma M, Al-Dwibe H, Elmaihub E, Babba $\mathrm{H}$, et al. Molecular diagnosis of Toxoplasma gondii infection in Libya. BMC Infect Dis. 2016;16:157. https://doi.org/10.1186/s12879016-1491-5 PMID:27083153 PMCID:PMC4833959

13. Gebremedhin EZ, Tadesse G. A meta-analysis of the prevalence of Toxoplasma gondii in animals and humans in Ethiopia. Parasit Vectors 2015; 8: 291. PMID:26017571 PMCID:PMC4449589

14. Gongora-Biachi R, Gonzalez-Martinez P, CastroSansores C, Alvarez-Moguel R, Pavia-Ruz N, LaraPerera D, et al. Antibodies against Toxoplasma gondii in patients with HIV in Yucatan. Rev Invest Clin Organ Hosp Enferm Nutr. 1997; 50(5):419-22.

15. Grant IH, Gold WM, Rosenblum M, Niedzwieki D, Armstrong D. Toxoplasma gondii serology in HIV infected patients: the development of central nervous system toxoplasmosis in AIDS. AIDS.1990; 4:519521. https://doi.org/10.1097/00002030-19900600000004 PMID:2386617

16. Hari K, Modi M, Mochan A, Modi G. Reduced risk of toxoplasma encephalitis in HIV-infected patients - a prospective study from Gauteng, South Africa. Int J STD AIDS. 2007; 18(8):555-8. https://doi. org/10.1258/095646207781439829 PMID: 17686219

17. Joseph P, Calderon MM, Gilman RH, Quispe ML, Cok J, Ticona E, et al. Optimization and evaluation of a PCR assay for detecting toxoplasmic encephalitis in patients with AIDS. J Clin Microbiol. 2002; 40, 4499-4503. https://doi.org/10.1128/JCM.40.12.44994503.2002 PMID:12454142 PMCID:PMC154600
18. Kodym P, Malý M, Beran O, Jilich D, Rozsypal $\mathrm{H}$, Machala L, et al. Incidence, immunological and clinical characteristics of reactivation of latent Toxoplasma gondii infection in HIV-infected patients. Epidemiol Infect. 2015;143(3):600-7. https://doi. org/10.1017/S0950268814001253 PMID:24850323

19. Laing RB, Flegg PJ, Brettle RP, Leen CL, Burns SM.. Clinical features, outcome and survival from cerebral toxoplasmosis in Edinburgh AIDS patients. Int. J. STD AIDS. 1996;7(4):258-64. https://doi. $\underline{\text { org/10.1258/0956462961917933 }}$ PMID: $\underline{8876356}$

20. Liesenfeld O, Montoya JG, Kinney S, Press C, Remington JS. Effect of testing for IgG avidity in the diagnosis of Toxoplasma gondii infection in pregnant women: experience in a US reference laboratory. $\mathrm{J}$ Infect Dis. 2001; 183: 1248e1253.

21. Lindström I, Kaddu-Mulindwa DH, Kironde F, Lindh J. Prevalence of latent and reactivated Toxoplasma gondii parasites in HIV-patients from Uganda. Acta Trop. 2006;100(3):218-22.

22. Mahmoudvand H, Saedi Dezaki E, Soleimani S, Baneshi MR, Kheirandish F, Ezatpour B, et al. Seroprevalence and risk factors of Toxoplasma gondii infection among healthy blood donors in south-east of Iran. Parasite Immunol 2015; 37: 362-67.

23. Malla N, Sengupta C, Dubey ML, Sud A, Dutta U. Antigenaemia and antibody response to toxoplasma gondii in human immuno deficiency virus infected patients. Br J Biomed Sci 2005, 28:104-109.

24. Mardani A, Keshavarz H, Hosseini Ghavanlooei S. Seroprevalence study of antitoxoplasmic antibodies ( $\operatorname{IgG}$ and $\operatorname{IgM}$ ) in individuals infected with HIV in Qom regional blood transfusion center. Iranian J Infect Dis Trop Med. 2004; 9(27):19-23.

25. Meisheri YV, Mehta S, Patel U. A prospective study of seroprevalence of toxoplasmosis in general population, and in HIV/AIDS patients in Bombay, India. J Postgrad Med. 1997;43:93-7.

26. Mohraz M, Mehrkhani F, Jam S, Seyed Alinaghi A, Sabzvari D, Fattahi F, et al. Seroprevalence of toxoplasmosis in HIV+/AIDS patients in Iran. Acta Medica Iranica. 2011; 49(4):213-218. 
75.Prevalence of Toxoplasma gondii Antibodies...

27. Montoya JG, Liesenfeld O. Toxoplasmosis. Lancet . 2004; 363: 1965-76.

28. Nasir IA, Shehu MS, Adekola HA. Anti-Toxoplasma gondii $\mathrm{IgG}$ avidity testing is necessary for diagnosis of acute toxoplasmosis. J Taibah Univ Med Sc. 2017; 12(1):e87-88.

29. Nissapatorn V, Kamarulzaman A, Init I, Tan LH, Rohela M, Norliza A, et al. Seroepidemiology of toxoplasmosis among HIV- infected patients and healthy blood donors. Med J Malaysia. 2002; 57(3):304-10.

30. Nissapatorn V, Lee C, Quek KF, Chee LL, Rohela M, Khairul Anuar A. Toxoplasmosis in HIV/ AIDS patients: a current situation. Jpn J Infect Dis . 2004;57:160-5.

31. Pappoe F, Cheng W, Wang L, Li Y, Obiri-Yeboah D, Nuvor SV, et al. Prevalence of Toxoplasma gondii infection in HIV-infected patients and food animals and direct genotyping of T. gondii isolates, Southern Ghana. Parasitol Res. 2017;116(6):1675-1685.

32. Robert-Gangneux F, Darde ML. Epidemiology of and diagnostic strategies for toxoplasmosis. Clin Microbiol Rev. 2012; 25: 264-96.

33. Rostami A, Keshavarz H, Shojaee S, Mohebali M, Meamar AR. Frequency of Toxoplasma gondii in HIV Positive Patients from West of Iran by ELISA and PCR. Iran J Parasitol. 2014; 9(4):474-81.

34. Shafiei R, Riazi Z, Sarvghad M, Galian Sharifdini M, Mahmoodzadeh A, Hajia M. Prevalence of IgG and IgM Anti-Toxoplasma gondii antibodies in HIV positive patients in northeast of Iran. Iranian J Pathol. 2011; 6:68-72.

35. Shimelis T, Tebeje M, Tadesse E, Tegbaru B, Terefe A. Sero-prevalence of latent Toxoplasma gondii in- fection among HIV-infected and HIV-uninfected people in Addis Ababa, Ethiopia: a comparative cross-sectional study. BMC Res Notes. 2009;.2:213.

36. Sukthana Y. Toxoplasmosis: beyond animals to humans. Trends Parasitol. 2006; 22(3):137-42. https:// doi.org/10.1016/j.pt.2006.01.007 PMID:16446116

37. Walker M, Zunt JR. Parasitic central nervous system infections in immunocompromised hosts. Clin Inf Dis 2005; 40:1005-1015. Walle F, Kebede N, Tsegaye A, Kassa T. Seroprevalence and risk factors for Toxoplasmosis in HIV infected and non infected individualsin Bahir Dar, Northwest Ethiopia. Parasit Vectors. 2013; 6(1):15. https://doi.org/10.1186/1756-3305-615 PMID:23324409 PMCID:PMC3556116

38. Wang ZD, Wang SC, Liu HH, Ma HY, Li ZY, Wei F, et al. Prevalence and burden of Toxoplasma gondii infection in HIV-infected people: a systematic review and meta-analysis. Lancet HIV. 2017; 4(4):e177-188.

39. Welker Y, Molina JM, Poirot C, Ferchal F, Decazes JM, Lagrange P, et al. Interaction between human immunodeficiency virus and Toxoplasma gondii replication in dually infected monocytoid cells. Infect Immun. 1993; 61: 1596-98.

40. Yohanes T, Debalke S, Zemene E. Latent Toxoplasma gondii Infection and Associated Risk Factors among HIV-Infected Individualsat Arba Minch Hospital, South Ethiopia. AIDS Res Treat. 2014;2014:652941.

41. Zeleke AJ, Melsew YA. Seroprevalence of Toxoplasma gondii and associated risk factors among HIV-infected womenwithin reproductive age group at Mizan Aman General Hospital, Southwest Ethiopia: a cross sectional study. BMC Res Notes. 2017; 10(1):70. https://doi.org/10.1186/s13104-017-2390-6 PMID:28126016 PMCID:PMC5270335

\section{How to Cite This Article}

Bavand A, Aghakhani A, Mohraz M, Banifazl M, Karami A, Golkar M, Babaie J, Saleh P, Mamishi S, Ramezani, A. Prevalence of Toxoplasma gondii Antibodies and DNA in Iranian HIV Patients. Iranian Journal of Pathology. 2019; 14(1): 68-75. 